\title{
DIVINE REVELATION IN THE PHILOSOPHICAL ESSAYS OF AL-FĀRĀBI IN COMPARISON WITH THE MYSTICAL THOUGHTS OF IBN 'ARABI
}

Ghorbanali Karimzadeh Gharamaleki

University of Tabriz, East Azerbaijan, Iran

E-mail: g.karimzadeh@tabrizu.ac.ir

Abdullah HosseiniEskandian

University of Tabriz, East Azerbaijan, Iran

E-mail: hosseinieskandianabdullah@gmail.com

\author{
Nur Hidayat Wakhid Udin \\ Sunan Ampel State Islamic University Surabaya, Indonesia \\ E-mail: nh.wakhidudin@uinsby.ac.id
}

\begin{abstract}
One of the most important concepts discussed in Islamic sciences is the explanation of divine revelation. Al-Fārābī and Ibn 'Arabī are among the leading Islamic thinkers who have tried to explain divine revelation according to their style and school of thought. Al-Fārābī considers revelation as receiving knowledge from the active intellect while Ibn 'Arabī considers it as the revelation of abstract rational meanings from God to the prophets. Examining and comparing their views on divine revelation can acquaint us with their thoughts on how the revelation and its quality came about as well as their intellectual similarities and differences. Employing a descriptive-analytical method, this article examines the essence of revelation in the thought of these two scholars. It also analyzes the quality and degree of revelation in their minds. The discussion ends with a comparison of their views on this issue. Al-Fārābī and Ibn 'Arabī consider revelation as a divine command revealed by God directly or indirectly to the prophets to guide their people. While al-Fārābi tries to explain the revelation based on the prominent role of the Active Intellect, Ibn 'Arabi pays attention to the issue of divine grace in sending of the revelation and the imagination of the prophets.
\end{abstract}

Keywords: Revelation; al-Fārābī; Ibn 'Arabī; Active Intellect; Prophet.

Article history: Received: 11 November 2019 | Revised: 11 January 2021 | Accapted: 11 May 2021 | Available online: 02 June 2021 


\section{How to cite this article:}

Gharamaleki, Ghorbanali Karimzadeh, Abdullah HosseiniEskandian, and Nur Hidayat Wakhid Udin. "Divine Revelation in the Philosophical Essays of al-Fārābī in Comparison with the Mystical Thoughts of Ibn 'Arabì". Teosofi: Jurnal Tasanuf dan Pemikiran Islam 11, no. 1 (2021): 122 141. https://doi.org/10.15642/teosofi.2021.11.1.122-141.

\section{Introduction}

According to Islamic discourse, revelation is the divine word revealed to the prophet by the angel of revelation, and the prophet conveys it to the people. In Islam, the philosophy of revelation is God's will to guide humankind and save them. This is because they cannot achieve happiness with their intellect alone. ${ }^{1}$ Therefore, they need divine guidance in which revelation meets their need. Man's relationship with the transcendental world and receiving grace and perfection from that world has always been one of the topics that have occupied the human mind throughout the history of thought. ${ }^{2}$ Many thinkers and sages with different religions and schools of thought have discussed and put great attention on it. Al-Fārābī and Ibn 'Arabī are among Muslim thinkers who have paid attention to the issue of revelation in their works.

Al-Fārābì has explained the revelation in the light of the special role of the active intellect in this regard. He has also explained the revelation as receiving the grace and divine word from the active intellect. This knowledge goes through a stage in the power of the narrator and the imagination of the prophet. It subsequently reaches the hearing and opinion of people in the form of words at the level of the world of sense. ${ }^{3}$ Ibn 'Arabi also considers revelation as the receipt of abstract rational meanings from the transcendental world by the prophet directly or indirectly, which through different levels and the

\footnotetext{
1 William A. Graham, Divine Word and Prophetic Word in Early Islam (The Hague: Mouton Publishers, 1977), 266.

2 Abdullah Saeed, 'Rethinking 'Revelation' as a Precondition for Reinterpreting the Qur'an: A Qur'anic Perspective” Journal of Qur'anic Studies 1, no. 1 (1999), 93-114. http://www.jstor.org/stable/25727946; Khalil Andani, "Revelation in Islam: Qur'ānic, Sunni, and Shi i Ismaili Perspectives” (PhD diss., Harvard University, 2020); Muhammad Aiman Awalluddin, "Redefining Rational and Revelation into the Islamic Systemology Concept", Teosofi: Jurnal Tasawuf dan Pemikiran Islam 9, no. 2 (2019), 407-427. https://doi.org/10.15642/teosofi.2019.9.2.407-427.

3 Abū Naṣr al-Fārābī, Mabādi' Arā' Abl al-Madina al-Fädila, trans. Richard Walzer (Oxford: Clarendon Press, 1985), 50.
} 
use of his powers, especially the power of imagination, he finally communicates to people through human levels. ${ }^{4}$

Revelation has been an issue that has occupied the human mind since the time of the resurrection of the prophets and their acknowledgment of the divine word. Although no one but God and the prophet who receives revelation is well aware of how to issue and receive revelation, throughout the history of thought, thinkers have always discussed this and even expressed the quality of revelation and its ejaculation levels. In the meantime, al-Fārābī and Ibn 'Arabī are among the thinkers who have provided opinions on this subject.

So far, to the best of our knowledge, no research has been done to examine and compare the views of al-Fārābī and Ibn 'Arabī on revelation. Therefore, in this preliminary study we attempt to comparatively analyze the essence of the concept of revelation, its quality, and its degree in the light of al-Fārābî's and Ibn 'Arabì's views.

We have found, indeed, several works such as "The Spiritual Ascension: Ibn 'Arabī and the Míràj Part II" written by James Winston Morris 5 , "Revelation According to al-Farabi and Ibn Sina" written by Muhammad Hadi Mullazade', Logos and Revelation: Ibn 'Arabi, Meister Eckbart, and Mystical Hermeneutics written by Robert Dobie ", "Revelation in the Perspectives of Ibn 'Arabi" written by Yadollāh Dādjoo", a specific study of the ideas of al-Fārābī and Ibn 'Arabī with other thinkers has been done. However, the existing researches emphasize more on explaining what revelation is while the axes of the present research have not been deeply examined.

The question of what revelation is and how it has been issued and received has become a widely debated issue among mankind since the prophets propagated it to their people. For those who do

${ }^{4}$ Muhy al-Dīn Ibn 'Arabī, al-Futūḥāt al-Makekiyyya, Vol. 2 (Cairo: Bulāq, 1911), $327-$ 329.

${ }^{5}$ James Winston Morris, "The Spiritual Ascension: Ibn 'Arabī and the Mi'rāj Part II", Journal of the American Oriental Society 108, no. 1 (1988), 63-77. DOI: $10.2307 / 603246$.

6 Muhammad Hadi Mullazade, "Revelation in Avicenna's and Farabi's Opinions", Journal of Philosopical Theological Research 10, no. 4 (2009), 245-260. DOI: 10.22091/PFK.2009.206.

7 Robert Dobie, Logos and Revelation: Ibn 'Arabi, Meister Eckhart, and Mystical Hermeneutics (Washington: The Catholic University of America Press, 2010).

${ }^{8}$ Yadollāh Dādjoo, "Revelation in the Perspectives of Ibn 'Arabi", S-Erfani 1, no. 16 (2012), 139-156. 
not believe in the existence of God and deny the existence of the transcendental world, the doctrine of revelation may not be a challenging matter and a questionable issue. However, for the believers in the divine religions and monotheism, the issue of revelation is essential in terms of the source of its issuance and how the prophet receives it. In Islam, revelation is the word of God which comes literally and spiritually from Him. It is revealed to the prophets to guide people. al-Fārābī and Ibn 'Arabī, among the greatest Muslim thinkers, have discussed the nature of revelation, its quality, its degree, and other related issues. Their ideas on the issue have strongly influenced the views of subsequent Muslim scholars.

To systematically limit the discussion of this study, we propose several questions on firstly, what definition of revelation did al-Fārābī and Ibn 'Arabi express? Secondly, in the definition of revelation what phrases and expressions did al-Fārābī and Ibn 'Arabī emphasize and explain revelation based on it? Thirdly, what is the quality of revelation from their point of view? Fourth, what is the level of revelation according to them? Fifth, what are the differences and intellectual similarities between al-Fārābī and Ibn 'Arabī in explaining revelation?

\section{Defining and Expressing the Nature of Revelation}

Al-Fārābì has tried in his works to explain revelation based on the prophet's relationship with the active intellect, and on the other hand, the imaginative and eloquent power of the prophet. He was the first Islamic philosopher to explain the nature of revelation through active intellect, linking the impartiality of rationalities to potential intellect with their impartation to the imaginative power. ${ }^{9}$ Al-Fārābi believes that prophet uses imagination in receiving and communicating revelation from the two areas of receiving revelation from the active intellect and inducing it to the people. He believes that the prophet's imagination is sufficient and faithful to be able to play a role in this stage. Al-Fārābi used the theory of imagination to explain the concept of revelation for two reasons, namely perceiving and receiving revelation from the active intellect and the other because the prophet conveyed the revelation to the people. ${ }^{10}$

\footnotetext{
${ }^{9}$ al-Fārābī, Mabādi’ Arā' Abl al-Madina al-Fädilla, 15-16.

${ }^{10}$ Gürbüz Deniz, "Al-Farabi on Divine Knowledge”, Journal of Islamic Research 2, no. 2 (2009), 25-26.
} 
In his works, after proving the existence of God, al-Fārābī discusses the attributes that can be attributed to Him. Among these attributes is "knowledge", which is the basis for the revelation of the first being. This attribute can only be said to be immutable; because the "first being" has knowledge of objects with rational means and rational science does not change, but science that uses sense is variable. ${ }^{11}$ Also, this knowledge is a simple rational knowledge that does not cause multiplicity and is the imparting of the world and the relationship that it establishes with each of the details: "God's knowledge is a rational and simple science, and the little knowledge that a person has is also given to Him, is by God and does not cause multiplicity". An example of this is that there is a debate between a wise person and his friend and his friend says a long word and the wise person remembers that long word to bring the answer to everything that his friend has said, without having to answer his points in detail beforehand. ${ }^{12}$ Of course, al-Fārābī states that the knowledge of God cannot be compared to the knowledge of other beings because the intellect and reason of God are different from other beings..$^{13}$ In al-Fārābī's philosophical system, the first existing science with such characteristics is the source of revelation. ${ }^{14}$

Al-Fārābì has defined revelation as "the process of degrading knowledge from God to the prophet" and also "the descent and degradation of divine truths from the position and rank of general reason in the imaginary world for the person of the prophet". ${ }^{15} \mathrm{He}$ has also defined revelation as the impartation of active intellect to the passive intellect through the mediation of used intellect. ${ }^{16}$

According to al-Fārābī, revelation is a kind of divine grace that God deems the prophets worthy of being ejaculated by the active

${ }^{11}$ Deborah L. Black, "Avicenna on Self-Awarness and Knowing that One Knows", in Shahid Rahman, Tony Street, Hassan Tahiri (eds.), The Unity of Science in the Arabic Tradition: Science Logic Epistemology and Their Interactions (Netherlands: Springer, 2008), 59-61.

12 Abū Naṣr al-Fārābī, Iḥsā' al-'Ulūm, ed. 'Uthmān Amīn (Egypt: Dār al-Fikr al'Arabī, 1949), 99-101.

13 Yasin Ceylan, "Some Remarks on al-Fārābî̀s Views on the Relationship between Philosophy and Religion", Islamic Studies 33, no. 1 (1994), 77-81. http://www.jstor.org/stable/20840157.

14 al-Fārābī, Iḥsā’ al-'Ulùm, 91-98.

15 al-Fārābī, Mabādi' Arā' Abl al-Madìna al-Fādila, 269.

${ }^{16}$ Hasan Hanafì, Min al-Naql ilā al-Ibdā, Vol. 4 (Cairo: Dār Qubā’ li al-Ṭibā‘a wa alNashr wa al-Tawzī‘, 2001), 79-80. 
intellect due to their high level of intellect and spirit and this ejaculation, which is at the level of the narrators of the prophets, must reach the level of their imagination so that it can be understood by human beings so that they can cling to it and be guided.

Al-Fārābì connects the doctrine of revelation to its political aspect and considers it as one of the characteristics of the boss of the utopia and says: "The boss of the utopia is a person who does not need anything and God has given him everything, and he knows many sciences that a person cannot find those sciences with material means and the head of utopia has become aware of those sciences through divine revelation and words". ${ }^{17}$ It is obvious that in this sense, the head of the utopia in al-Fārābì's thought is the same prophet connected to the revelation and the word of God, and because he is connected to the source of divine knowledge, this is what realizes the prosperity of utopia.

The important point in explaining revelation in al-Fārābìs thought is the role of active intellect or, in religious terms, the angel of revelation. He believes that after the orthodox and imaginative power of the prophet, he reached perfection and exaltation and was subjected to receiving the divine word from God, the prophet will gain more blessings due to his connection with the active intellect, which will receive him in receiving the divine word. According to alFārābi, the revelation of the ejaculation of truths and knowledge from God to the prophets is done through intermediate or direct means. The important aspect in defining revelation is the "sending" by God and the "receiving" by the prophet.

As for the revelation in Ibn Arabi's view, he considers revelation to be specific to the prophets, who have not attained that status and have not attained intellectual and intuitive perfections; they are also deprived of its existence. He also believes that revelation is achieved through effort and the role of God's grace and forgiveness in the selection of his special servants. In this regard, he states: "Revelation is from God and not from the souls of the prophets or their thoughts and intellectual structures; as God says "It is sent by God the wise"18 and also said:" There is no falsehood behind it and in

7 Abū Naṣr al-Fārābī, Opinions of the People of the Utopia, trans. Seyed Jafar Sajjadi (Tehran: Tahoora Publications, 1981), 49.

18 al-Qur'ān, 41: 42. 
front of it" 19 and this is because the book that was revealed to the prophet is from God and not from man and his thought. ${ }^{20}$

Ibn 'Arabi defines revelation as: "Revelation is a reference that replaces the phrase. The phrase is a bridge that the audience crosses to reach the purpose; that is why it is called the phrase, but in revelation, it is not the passage from one thing to another; rather, it refers to the same meaning and purpose, and because it happens quickly and the understanding and concept of it is a truth, and revelation is, in fact, the same as the first concept and the first understanding. ${ }^{21} \mathrm{He}$ also says in the definition of a revelation: "Revelation is the revealing of abstract intellectual meanings in sensory forms that are bound in the level of imagination and are among the evidence of sense in the level of perception and the level of imagination. ${ }^{22}$

Ibn 'Arabi believes that revelation before revealing to the prophet is simple and abstract and does not have multiplicity. He states that this simple and abstract revelation is manifested in the world of sensations and in the prophet's thought in the form of concepts and words, and the prophet also communicates these manifested concepts and words to the people. Ibn 'Arabī states that the perception of the teachings of revelation is of the type of intuitive knowledge in which no error occurs. Because it is from God, it cannot be considered a defect, and revelation is the divine knowledge that is from God, and it leads people through the prophet. ${ }^{23}$

According to Ibn 'Arabī, revelation is first related to the senses and then enters into abstract matters outside the senses. Also, the beginning of revelation is only with dreams, whether in sleep or waking, and the meaning of revelation is the truths with which the divine law is established. Ibn 'Arabī believes that revelation is a kind of revealing and induction of meanings from God to the prophet, and revelation itself is a kind of way of knowledge and cognition along with reason and sense. In the light of it, great knowledge is revealed

\footnotetext{
19 Ibid.

${ }^{20}$ Ibn 'Arabī, al-Futūhāt al-Makkeivyya, Vol. 4, 269.

${ }^{21}$ Ibid., Vol. 8, 329.

22 Ibid.

${ }^{23}$ Franz Rosenthal, "Ibn 'Arabī between "Philosophy" and "Mysticism": "Sūfism and Philosophy Are Neighbors and Visit Each Other". Fa-inna At-tasawnuf Wa-ttafalsuf Yatajāwarāni Wa-yatazāwarānı", Oriens 31 (1988): 1-35. DOI: 10.2307/ 1580724.
} 
to the prophet, and he guides by expressing those teachings. In Ibn 'Arabì's thought, revelation is a divine gift to the servants. They receive the divine message and word to prosper in this world and the hereafter, and by following the divine commands, they provide a kind of blissful life for themselves and others.

\section{The Quality of Revealing Revolution}

What is evident from al-Fārābî's writings is that he considers the prophet to receive revelation from God in three stages, which are:

First, connection to active intellect: At this stage, the prophet succeeds in receiving grace from the active intellect. Al-Fārābi considers this success apart from the study of formal sciences by the prophet and he believes that this success in receiving divine revelation and grace from the active intellect is the divine grace and blessing on the prophet, who considered his soul worthy of receiving his words and teachings.

Explaining this stage of receiving revelation, al-Fārābì states: "When a person acquires the principles of science through the imagination, he does not need anything in explaining its principles because he has received this knowledge from the active intellect". ${ }^{24}$ At this stage, the orthodox power of the prophet has passed from the actual level and has reached the highest degree that the intellect is used and can comprehend the different things from sense and matter.

Al-Fārābī believes that the revelation received by the active intellect by the prophet is not acquired but divine grace and says: "When a person leaves the potential intellect and moves towards the actual intellect, and then acquires the necessary levels in the actual intellect and moves towards the used intellect, all this is a grace and forgiveness from God and due to the high intellectual and spiritual levels of that person, God considers him worthy of receiving a revelation that no one can reach such a level except the prophet". 25

In fact, this aspect of al-Fārābì's statements can be considered as the ejaculation of revelatory verses by Gabriel to the prophet,

24 al-Fārābī, Iḥsā' al-'Ulūm, 12-13; Majid Fakhry, al-Farabi, Founder of Islamic Neoplatonism: His Life, Work, and Influence (Oxford: OneWorld, 2002), 70; Majid Fakhry, A History of Islamic Philosophy (New York: Columbia University Press, 2004), 124.

25 al-Fārābī, Iḥsā’ al-'Ulùm, 10. 
which the prophet receives revelatory verses from the angel of revelation or, in al-Fārābî's words, active intellect.

Second, the emergence of revelation in the prophet's imagination: al-Fārābī believes that in order to receive divine revelations and revelatory teachings, the prophet's imagination must have reached the highest degree of human perfection in order to be able to understand those teachings. After receiving the divine teachings by connecting the prophet to the active intellect, those teachings appear in the imagination of the prophet, and it is here that the imaginative power of the prophet, with the power and capability he has acquired through the attainment of perfection, turns the general intellects into parts.

From al-Fārābī's point of view, the prophet's imagination is completely obedient and submissive to the power of reason, and whatever the power of reason in general receives must be manifested in part in the power of imagination.

Al-Fārābi considers the imaginative power of the prophet as active as the rational power connected to the active intellect, and for this reason, in his opinion, no mistake is made in converting this general knowledge into partial knowledge in the imaginative power of the prophet. ${ }^{26}$

Third, revealing revelation to the sense of appearance and creation of words: since the rational and imaginative power of human beings is at the lowest levels of perfection, and like the rational and imaginative power of the prophet, it cannot comprehend the teachings; hence, that knowledge must be reduced to the form of imaginary forms in order to be understood through the external senses, such as what is read or heard.

Al-Fārābì states that what is degraded from the active intellect in the form of imaginary forms and then enters the stage of the prophet's senses is ultimate perfection, beauty, and good. ${ }^{27}$

One of the most important missions of the prophet is to convey the message and the word of God, and this is what gives meaning to guidance and the philosophy of revelation of knowledge and revelatory verses. It is in this stage of revelation that the teachings adopted by God and by the active intellect, which are first entered in the orthodox power of the prophet and then in the imaginative

\footnotetext{
${ }^{26}$ Ibid.

${ }^{27}$ al-Fārābī, Mabādi' Arä' Abl al-Madina al-Fädịla, 93-94.
} 
power, are communicated to human beings in the form of words and speech, so that human beings can gain a comprehensive understanding of the divine revelations with their external senses, in order to be guided.

In fact, the words of the prophet, while having an unseen origin and originating from God, appear in the form of words and phrases in order to be perfectly appropriate to the ears of the people who live in this world. It is here that we can say that the word of the prophet is "two-sided". The two-sidedness of the word of the prophet means that "revelation" is the word of God, and this word reaches the people through his message, and at the same time it is appropriate for the people of this world and appears in time and space. Also, revelation is dependent and continuous on the origin of existence, that is, God, and is considered a sign of the unseen and transcendental world. ${ }^{28}$

Al-Fārābî considers the soul of the prophet as a sacred thing that can receive divine knowledge and the word of revelation and says: "The prophet has a holy soul that receives divine grace and mercy at the beginning and has a high rank that always receives from God and receives all its knowledge from God, which is either directly or through intellect". ${ }^{29}$

Al-Fārābì believes that all intellects enter the intellect of the prophet through the active intellect and then are imparted to his imagination, and thus the soul of the prophet is not empty of any intellects and has all perfections in every sense.

According to al-Fārābī, the imagination of the prophet is perfect, and this has two benefits; the first is that it causes the external sensations that enter the imagination not to overpower the imagination in such a way as to pervade its entire field, and the second is that in this way the imagination does not fully serve the rational power and can have its own actions.

As for Ibn 'Arabī, he believes that the revealing revelation verses are done through the angel of the revelation in two ways; either the angel of the revelation induces the words and concepts of revelation in the heart of the prophet, or it descends physically and

28 Michael Sweeney, "Greek Essence and Islamic Tolerance: al-Farabi, al-Ghazali, Ibn Rushd”, The Review of Metaphysics 65, no. 1 (2011), 41-61. http://www.jstor.org /stable/23055682.

29 Richard Walzer, "Al-Fārābì's Theory of Prophecy and Divination", Journal of Hellenic Studies 27 (1957), 142. 
what is obligatory from God to hear the prophet and the prophet receives revelation. Therefore, revelation is received by the prophet both through sense and intuition. ${ }^{30}$

The angel of the revelation is not revealed except by the command of God. Of course, this does not mean that God commands them to reveal and descend from the rank of address; rather, when God wants to send revelation to man, he induces it in the souls of the angels. Then they do not find themselves worthy of the revelation that has been induced in them, and they realize that they must be revealed and induce that reality in human beings. Then they see the face of the person to whom it is to be revealed, in the form of faces. From those faces, they recognize the owner of the faces on the ground, and they descend on him and induce him with what has been induced in them, which this induction is interpreted as sharia and revelation. This type of revelation is specific to human beings; therefore, if it is attributed to God, as a rule, it is called the Qur'ān, the Torah, the Psalms, the Bible, and Scrolls. If it is attributed to God as an act, it is called a hadith, news, and opinion. ${ }^{31}$ Ibn 'Arabī believes that revelation has another quality: God reveals the concepts and teachings of revelation directly and without intermediaries on the prophet's heart. He believes that the highest level of revelation is this level, and receiving revelation in this way from God depends on the spiritual progress and ascension of the prophet, ${ }^{32}$ and God immediately reveals concepts on the heart of the prophet.

Ibn 'Arabi believes that the first appearance of the principles of the revelation of the prophets occurs as an intermediary between the world of sense and the absolute Mundus Imaginalis ('álam al-khayāt).33 Then it is perceived in the higher world. This is why he states that the first verses revealed to the Prophet Muhammad were done through dreams.

\footnotetext{
30 James Winston Morris, "Ibn 'Arabi's "Esotericism": The Problem of Spiritual Authority”, Studia Islamica, no. 71 (1990), 37-64. DOI: 10.2307/1595637.

31 Ibid.

32 Morris, "The Spiritual Ascension”, 65.

33 Henry Corbin, "Mundus Imaginalis, or the Imaginary and the Imaginal", in Swedenborg and Esoteric Islam, trans. L. Fox (West Chester: Swedenborg Foundation, 1995), 1; Rebecca Masterton, "Islamic Mystical Resonances in Fulbe Literature", Journal of Islamic Studies 19, no. 1 (2008), 36-58. http://www.jstor.org/stable /26200966.
} 
Ibn 'Arabī states that the soul of the prophet must rise to a level where he can first receive and comprehend revelation in the imagination and then in the world of absolute Mundus Imaginalis. In other words, to complete the reception and communication of revelation, both the angel of the revelation and the prophet's soul must go through imagination. Since imagination is an intermediary between the world of sense and absolute Mundus Imaginalis, by passing through it, they can become absolute Mundus Imaginalis. That is where divine revelation is revealed to the prophet by the angel of the revelation. The prophet communicates the divine revelation to the people in the form of human's words. ${ }^{34}$

\section{The Level of Revelation}

Before dealing with the revelation from the point of view of alFārābī, it should be noted that al-Fārābī divided the inner senses, which play a key role in receiving revelation from the prophet, into four categories: 1). Illustrated Power: this power stores the perceptible forms that it sends from the external senses to common sense. Common sense is the sense that lies between the external sense and the internal sense; 2). Imaginative: this power perceives and stores meanings that are not understood by the illustrated power; 3 ). Memory: this power is the storehouse of illusory perceptions and its relation to the power of illusion is like the relation of the illustrated power to common sense and tangible forms; and 4). Thought: this power includes both the reserves of the illustrated power and the reserves of the memory power and combines and decomposes them together. ${ }^{35}$

Al-Fārābi believes that revelation is in fact a reasonable degradation of the imaginary. He has tried to explain the quality of the revelation in the light of the imagination, which plays an essential role in explaining the concept of revelation and prophecy in his mind. Al-Fārābi believes that only the imagination of the prophets and some wise men goes beyond the animal level and that the general and the majority of people cannot develop their imagination in order to receive divine knowledge and because their imagination and their

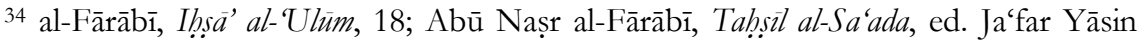
(Beirut: n.p., 1983), 73.

35 Abū Naṣr al-Fārābī, Risāla fì al''Aql, ed. Maurice Bouyges (Beirut: Imprimerie Catholique 1983), 15.
} 
imaginative power do not progress. As a result, their rational power does not progress and rise, and because their perception and rational power are at a low level and they are not able to understand those teachings. Therefore, there is no other way than for the prophet to convey the teachings of revelation to him from a rational form to an imaginary one.

One of the differences between the imagination of the prophet and the imagination of other human beings is that the power of the prophet while sleeping and waking, receives the concepts and details of things from the active intellect and is always engaged in acquiring meanings and concepts from the world of the soul.

Al-Fārābì, in terms of the rational aspect of the prophet's understanding of revelation, first places the level of intellect in the "material intellect", which is merely the talent and readiness to comprehend the rationals, "actual intellect" which is when the human soul acquires sciences and generalities and the issuance of rationalities are gathered in it and become actual from the potential state and the "used intellect" states that the intellect is able to comprehend the different forms of matter, and considers the rational aspect of the prophets to be related to the "used intellect" which is able to separate from the material world and finds things that are separate from the characteristics of the world of the senses, and so is the nature of the divine word. Al-Fārābi believes that the perception of revelation depends on having the rank of used intellect in terms of rational power, and from other aspects also requires its own characteristics, which ultimately, by bestowing grace from God, the heart and soul of the prophet are worthy of receiving words and concepts.

In terms of the imagination, if the human imagination is so perfect that it can make free itself from the clutches of other powers in the state of awakening and engage in rational imitations, then it is close to receiving revelation. According to al-Fārābī, the imaginative power of the prophets is dominated by the power of their intellect and covers what it receives from the intellect, and it even creates an image of different beings in the surrounding space, which is an example of predicting the future and informing about past events, the details of which are unknown. ${ }^{36}$

\footnotetext{
36 Walzer, "al-Fārābî’s Theory of Prophecy and Divination", 146; Sami S. Hawi, "Aspects of al-Fārābī's Thought in the Light of Ibn Tufayl's Criticism", Islamic Studies 34, no. 3 (1995), 297-303. http://www.jstor.org/stable/20840213.
} 
According to al-Fārābī, the perfection of the imaginative power is to be completely obedient to the rational power and to be attracted to it, and to perceive the teachings that the rational power receives by connecting to the active intellect in a human way and in the full meaning and concept and be able to make it comprehensible to other people who are at the lower levels of imagination, to become aware of the divine knowledge.

As for Ibn 'Arabī, he believes that revealing divine meanings and concepts from the world beyond the senses to the heart of the prophet is not sudden and goes through different levels that each level has its own characteristics that distinguish it from others. The revealing levels of revelation from Ibn 'Arabì's point of view include:

First, the level of intellect. At this level, the divine command, which is in the form of the same divine names, is revealed to the intellect in a voluntary manifestation, and revelatory concepts are manifested in the prophet's thought.

Second, the level of the soul. At this level, the revelatory concepts that have passed the level of intellect are manifested in the form of soul concepts and outside the material attributes on the soul of the prophet.

Third, the level of the empyrean. In this level, the concepts of revelation become the empyrean, and the empyrean in Ibn 'Arabî's thought is the first level of the world of creation.

Fourth, the level of the ultimate. After the manifestation of the revelatory concepts from the rank of the empyrean, they are manifested to the level of the ultimate, and in this level, the revelatory teachings and concepts appear in a way other than the one that was on it in the beginning.

Fiveth, the order of the Sidrat al-Muntaha. The divine command that is revealed is the divine, the intellectual, soul, empyrean, and ultimate; that is, the sum of the forms of everything that has passed in its path. Of course, it appears at the same level in each order until manifestation in the creatures' hearts. ${ }^{37}$

Sixth, the human level. The last level of revelation is that the concepts and teachings of revelation are fully received by the prophet and are communicated to the people at this stage.

\footnotetext{
37 Muhy al-Dīn Ibn 'Arabī, Fușūs al-Hỉkam, ed. Abū al-A'lā al-'Afífĩ (Beirut: Dār alKitāb al-'Arabī, 2006), 28-30.
} 
From Ibn 'Arabî's point of view, the revealing revelatory verses on the heart of the prophet and his imaginative and eloquent power is not such that people can easily understand it because human beings are at the lowest level of intellect and intuition and do not have the necessary perfection to understand the divine word, which is outside sensory features. Hence, divine revelation goes through different levels of revealing to be in the prophet's imagination in such a way that it can be understood by human beings in the world of sense, for example, to be heard or read. Of course, Ibn 'Arabī emphasizes that all levels of revelation from the prophet are divine, and the prophet does not make any change in the message of the divine word. The same word that is read and heard by man in the world of the senses is God's word and by his command.

Ibn 'Arabi considers the revealing revelation to be conditional on this level, because from his point of view because the initial state of revelation does not have the characteristics of the material world and is beyond the senses, it is incomprehensible to humans. They do not have the necessary talent to understand those concepts because it requires a special intellectual and spiritual perfection to which the prophets' souls are merely adorned and which other human beings lack. Hence, divine revelation goes through these levels until it is finally communicated to the prophet's people on the human level.

\section{Comparison of al-Fārābī and Ibn 'Arabī's Views}

The doctrine of divine revelation is one of the most important concepts in Islamic philosophy and mysticism, which philosophers refer to as receiving meaning from the first being, and mystics consider it as a grace from the Lord of the worlds to guide man. AlFārābi and Ibn 'Arabī have tried to explain the doctrine of revelation according to their style and school of thought. While al-Fārābī uses words and expressions such as "active intellect", "simple intellect", "first being" and so forth, Ibn "Arabī uses terms and expressions such as "arsh", "intuition", "evangelism" and so on.

Al-Fārābī and Ibn "Arabì believe that the sender of revelation is the "first being" and that he is the Eternal Creator who is free from all imperfections and all beings are His creatures. They consider revelation as the divine word and the guiding knowledge from God, which is revealed directly or indirectly to the prophet to realize the guidance of man and bring them out of error. Since they consider 
revelation as the word of the Eternal Creator, who is the highest degree of perfection in everything, they believe that his word also has the highest degree of eloquence and rhetoric, which no words can compete with it and this is the word that gives meaning to the philosophy of prophets' call and the explanation of the sharia.

Al-Fàrābi placed the position of the prophet below the philosopher and stated that the philosopher is connected to the active intellect through the powers of reason, while the prophet is connected through the imagination. However, commentators on alFārābî̀s works have defended him in this regard, stating that al-Fārābī refers to the philosopher and sage as the prophet who is connected to the source of revelatory and divine sciences. Unlike al-Fārābī, Ibn 'Arabi considered the rank of the prophets to be the highest human rank, which can only be achieved through the advancement of the soul and the power of reason as well as divine grace. However, with the promise that was mentioned, al-Fārābī also believes that the rank of the prophets is the highest human rank.

According to al-Fārābī, the prophet is raised during the revelation and connects to the world of angels. However, according to Ibn 'Arabi, it is the angel of revelation who descends on the prophet during the revelation and reveals revelatory verses to him.

According to al-Fārābī, the prophet can connect with the active intellect and acquire divine knowledge whenever he wants, but according to Islamic teachings, the revelation of divine knowledge, which is interpreted as revelation, depends on God's will and God willing. In other words, it can be stated that unless God allows revelation will not be revealed to the prophet. It is obvious that with this basic interpreter of al-Fārābì's thoughts, concepts such as death and cessation of revelation will have no place in meaning.

Al-Fārābì has also paid attention to the political aspect in explaining the revelation and considers receiving revelation as one of the high characteristics of the head of the utopia. However, the head of the utopia is none other than the prophet and this is why, because all things are done in the light of divine commands, nothing happens in the utopia except the transcendence of the soul, and one of the main axes of the utopia in al-Fārābìs thought is the receiving of knowledge by the prophet by the active intellect. On the other side, Ibn 'Arabi did not pay attention to the political aspect of revelation and did not explain this aspect of revelation in his works. 
In defining revelation, al-Fārābī has tried to define divine revelation in the light of active intellect and considers revelation as the induction of meanings and knowledge by active intellect on the prophet. Ibn 'Arabi, on the other hand, considers revelation as the ejaculation of abstract rational meanings in sensory forms, which is bound in the level of imagination and is one of the evidence of sense in the level of tangible and imaginary level. Ibn 'Arabi also proves the divinity of revelation by being taken from verses from the Holy Qur'àn, while al-Fārābī did not pay attention to such an aspect of divine revelation.

Al-Fārābi explains the revelation from the manifestation of the powers of reason and considers the connection to the active intellect, the emergence of revelation in the imaginative power of the prophet, and the degradation of revelation to the level of appearance as the qualities of revelation to the prophet. In his works, al-Fārābì did not express revelation directly from God and without the mediation of the angel of revelation or, in his an apt term is, "active intellect". This may be due to the fact that he considered the prophet in the general sense of the word and that only some prophets can receive revelation directly, which is considered the most difficult type of revelation to receive. However, Ibn 'Arabī considers the sending of the revelation to the prophet to be mediated and direct, which is mediated by the angel of revelation or in the Qur'ānic interpretation, "Rūḥ al-Amin", and is also performed directly by God on the heart of the prophet. In the quality of the revelation, al-Fārābì emphasizes the intellectual aspect of the prophet's powers in receiving revelation, but Ibn 'Arabī emphasizes the role of intuition and receiving revelation and its ejaculation on the prophet's heart.

In explaining the levels of revelation, al-Fārābī has a special emphasis on the imaginative power of the prophet, which is responsible for receiving revelation from the active intellect until it is censored and communicated to the people. Ibn 'Arabì has also stated for those six stages and finally the last stage of both philosophers ends with its communication to the people as they believe that its initial stage is done by God and directly or indirectly by God.

It should be noted that although al-Fārābī and Ibn 'Arabī propose different approaches to explain revelation, they commonly believe that revelation is a kind of divine word revealed by God onto the prophets to explain His sharia in order to prevent humankinds 
from erroneously misguided deeds and bring them to light and guidance.

\section{Concluding Remarks}

One of the most important concepts in the Abrahamic religions is divine revelation, which is why these religions are also called revelatory religions. In the Islamic world, al-Fārābī and Ibn 'Arabī are among prominent thinkers who have tried to explain divine revelation based on Islamic wisdom and thought. Al-Fārābī considers revelation as the receipt of knowledge by the active intellect, which finally enters the narrator and imagination of the prophet, and with this quality, it becomes a sensory and verbal level, and finally it is communicated to the people. Ibn 'Arabī also considers revelation to be the receipt of abstract rational meanings from God, which is either revealed directly by God to the prophet's heart or is revealed through an angel and eventually it is communicated to the people in the communication stage.

Al-Fārābì and Ibn 'Arabī have tried to provide a logical explanation of revelation, which finally, by describing the quality of its revelation and also expressing its levels, consider revelation in order to guide people and give meaning to the philosophy of guidance by explaining the sharia. However, there are obvious differences between the ideas of al-Fārābi and Ibn 'Arabī in explaining revelation, which is obvious according to the philosophical school of al-Fārābì as well as the mystical school of Ibn 'Arabì and the difference between philosophy and mysticism. Regardless of their difference approaches, they share a common idea that revelation is the divine word in which the prophets have no involvement and possession and by which they guide the people.

\section{Bibliography}

Andani, Khalil. "Revelation in Islam: Qur'ānic, Sunni, and Shi 'i Ismaili Perspectives". PhD diss., Harvard University, 2020.

'Arabī, Muhyy al-Dīn Ibn. al-Futūḥāt al-Makekiyya, Vol. 2. Cairo: Bulāq, 1911.

----. Fusūss al-Hikeam, ed. Abū al-A'lā al-'Afîfì. Beirut: Dār al-Kitāb al'Arabī, 2006.

Awalluddin, Muhammad Aiman. "Redefining Rational and Revelation into the Islamic Systemology Concept", Teosofi: Jurnal Tasawnf 
dan Pemikiran Islam 9, no. 2, 2019. https://doi.org/10.15642/teosofi.2019.9.2.407-427.

Black, Deborah L. "Avicenna on Self-Awareness and Knowing that One Knows", in Shahid Rahman, Tony Street, Hassan Tahiri (eds.), The Unity of Science in the Arabic Tradition: Science Logic Epistemology and Their Interactions. Netherlands: Springer, 2008.

Ceylan, Yasin. "Some Remarks on al-Fārābī's Views on the Relationship between Philosophy and Religion", Islamic Studies 33, no. 1, 1994. http://www.jstor.org/stable/20840157.

Corbin, Henry. "Mundus Imaginalis, or the Imaginary and the Imaginal", in Swedenborg and Esoteric Islam, trans. L. Fox. West Chester: Swedenborg Foundation, 1995.

Dādjoo, Yadollāh. "Revelation in the Perspectives of Ibn 'Arabi", $S$ Erfani 1, no. 16, 2012.

Deniz, Gürbüz. "Al-Farabi on Divine Knowledge", Journal of Islamic Research 2, no. 2, 2009.

Dobie, Robert. Logos and Revelation: Ibn 'Arabi, Meister Eckhart, and Mystical Hermenentics (Washington: The Catholic University of America Press, 2010.

Fakhry, Majid. A History of Islamic Philosophy. New York: Columbia University Press, 2004.

----. al-Farabi, Founder of Islamic Neoplatonism: His Life, Work, and Influence. Oxford: OneWorld, 2002.

Fārābī (al), Abū Naṣr. Iḅṣā' al- Ulūm, ed. 'Uthmān Amīn. Egypt: Dār al-Fikr al-'Arabī, 1949.

----. Opinions of the People of the Utopia, trans. Seyed Jafar Sajjadi. Tehran: Tahoora Publications, 1981.

-----. Risäla fi al-'Aql, ed. Maurice Bouyges. Beirut: Imprimerie Catholique 1983.

-----. Tahşil al-Sa'ada, ed. Ja'far Yāsin. Beirut: n.p., 1983.

----. Mabädi' Arä' Abl al-Madina al-Fädila, trans. Richard Walzer. Oxford: Clarendon Press, 1985.

Graham, William A. Divine Word and Prophetic Word in Early Islam. The Hague: Mouton Publishers, 1977.

Ḥanafì, Hẹasan. Min al-Naql ilā al-Ibdā, Vol. 4. Cairo: Dār Qubā' li alTibā'a wa al-Nashr wa al-Tawzī', 2001.

Hawi, Sami S. "Aspects of al-Fārābî's Thought in the Light of Ibn Tufayl's Criticism”, Islamic Studies 34, no. 3, 1995. http://www.jstor.org/stable/20840213. 
Masterton, Rebecca. "Islamic Mystical Resonances in Fulbe Literature", Journal of Islamic Studies 19, no. 1, 2008. http://www.jstor.org/stable/26200966.

Morris, James Winston. "Ibn 'Arabi’s "Esotericism”: The Problem of Spiritual Authority", Studia Islamica, no. 71, 1990. DOI: $10.2307 / 1595637$.

----. "The Spiritual Ascension: Ibn 'Arabī and the Mi'rāj Part II", Journal of the American Oriental Society 108, no. 1, 1988. DOI:10.2307/603246.

Mullazade, Muhammad Hadi. "Revelation in Avicenna's and Farabi's Opinions", Journal of Philosopical Theological Research 10, no. 4, 2009. DOI: 10.22091/PFK.2009.206.

Rosenthal, Franz. "Ibn "Arabī between "Philosophy" and "Mysticism": "Sūfism and Philosophy Are Neighbors and Visit Each Other". Fa-inna At-tasawnuf Wa-t-tafalsuf Yatajāwarāni Wayatazūwarānı", Oriens 31, 1988. DOI: 10.2307/1580724.

Saeed, Abdullah. "Rethinking 'Revelation' as a Precondition for Reinterpreting the Qur'an: A Qur'anic Perspective" Journal of Qur'anic Studies 1, no. 1, 1999. http://www.jstor.org/stable/25727946.

Sweeney, Michael. "Greek Essence and Islamic Tolerance: al-Farabi, al-Ghazali, Ibn Rushd", The Review of Metaphysics 65, no. 1, 2011. http://www.jstor.org/stable/23055682.

Walzer, Richard. "al-Fārābī's Theory of Prophecy and Divination", Journal of Hellenic Studies 27, 1957. 